\title{
Diversification Strategy and Good Governance: Does It Affect Firm's Leverage?
}

\author{
Katiya Nahda1 ${ }^{*}$, Azaria Lionara Rahmadana ${ }^{2}$ \\ 1,2 Department of Management, Faculty of Business and Economics, Universitas Islam Indonesia \\ *Corresponding Author: katiya.nahda@uii.ac.id
}

\begin{abstract}
This paper aims to analyze whether firm diversification affects firm leverage in developing countries. This research model is based on the agency theory view that focuses on diversification in leverage through good governance mechanisms. The data comes from 43 companies from 215 observation companies listed on the Indonesia Stock Exchange in the 2014-2018 period, supporting the co-insurance hypothesis; our findings suggest a positive effect of diversification on debt levels. Our findings show that cost advantages occur in diversified firms, including higher debt ratios in the firm's capital structure. These effects are more substantial when firms have better corporate governance. These findings add value to the existing literature on the relationship between firm diversification, corporate management, and leverage and can be helpful for managers and policy-makers regarding the evaluation of diversification strategy and corporate governance implementations in Indonesia that has been widely studied.
\end{abstract}

Keywords: Corporate Governance; Diversification strategy; Leverage

\section{INTRODUCTION}

The issue of corporate diversification has been widely studied and received considerable attention from academics and practitioners. It is well known as a strategic tool used by managers to improve the company's performance in these dynamic environments, becoming increasingly challenging and more complex. Managers have to diversify more of their business to deal with a higher level of uncertainty. Companies need to improve behavior and company performance to gather affiliated companies in one business group. (Colli \& Colpan, 2016).

However, diversification has been the subject of debate for many years, whether it brings more advantages or disadvantages (Delbufalo, Poggesi, \& Borra, 2016; Lee, Hooy, \& Hooy, 2012). Confounding factors affect the Relationship between diversification and performance so that it looks biased. (Ahuja \& Novelli, 2017; Schommer, Richter, \& Karna, 2019). This happens in several firm characteristics (Levinthal \& Wu, 2010), the state of the institutional Environment (Ramaswamy, Purkayastha, \& Petitt, 2017), or the idiosyncratic situations of firms (Mackey, Barney, \& Dotson, 2017). On the one hand, single-segment 
firms are proven to have value discounts on diversified firms (Berger \& Ofek, 1995; Chen \& Chu, 2012; Gyan, Brahmana, \& Bakri, 2017; Ammann, Hoechle, \& Schmid, 2012; Kuppuswamy \& Villalonga, 2016). On the other hand, diversification is supported by proponents of diversification. (Guo, 2011; Tate \& Yang, 2015; Villalonga, 2004).

There are several potential benefits from diversification, such as reducing the risk of bankruptcy (Berger, Hasan, \& Zhou, 2010), the opportunity to exploit certain assets and utilize them in new markets (Elsas, Hackethal, \& Holzhauser, 2010; Sakhartov \& Folta, 2015), improve management skills and brand reputation (Wang, Ning \& Chen, 2014), a higher level of efficiency from internal capital allocation (Weston, 1970), increasing debt capacity (Lewellen, 1971), and the achievement of economic scope and economies of scale (Ljubownikow \& Ang, 2020). Despite all the benefits, diversification is not without its cost and risk. It might increase the operational costs due to a higher degree of asymmetric information within a firm (Purkayastha, Pattnaik, \& Pathak, 2021), an over-investment problem caused by higher managerial discretion (Jensen, 1986), inefficient capital allocation across divisions through cross-subsidization (La Rocca et al., 2018; Rajan, Servaes, \& Zingales, 2007), as well as the incentives for rent-seeking behavior (Scharfstein \& Stein, 2000).

Previous empirical studies show a lack of attention to diversification strategies and capital structure (La Rocca et al., 2009; Monteforte \& Stagliano, 2015). Interestingly, after a thorough examination of the capital structure, no consensus was reached regarding the role of diversification strategy and its effect on financial choices (Jouida \& Hellara, 2018). Therefore, we would like to investigate further about this relationship and contribute to the literature that shows mixed results on the effect of diversification strategy on capital structure.

Moreover, while diversified firms have access to a larger internal capital market, the investment driven by the controlling shareholders is inefficient due to the motivation to increase the firm performance rather than expand the group. (Glaser et al., 2013). So the company must strengthen financial management, which can reduce negative consequences from business diversification (Feng et al., 2021). Nevertheless, it should stay focused on stand-alone firms.

Due to the rapid growth of large corporations in Indonesia, it is interesting to investigate how diversification affects a firm's financial decisions. Halabi et al.'s (2021) research show an inverse U-relationship between international diversification and the firm's credit score. The risk-reducing effect of diversification leads to better credit scores based on an opinion based on economic resources and transaction costs. The co-insurance hypothesis introduced by Lewellen (1971) explains how diversified firms can reduce the default risk through the imperfect cash flow correlations between business units. The imperfect correlations will reduce cash flow variability, thereby reducing the risk of bankruptcy through income smoothing.

From the co-insurance perspective, each business unit is viewed as a stand-alone firm. In other words, a diversified company is a type of company that has multiple singlesegment. It enables them to transfer financial resources from business units that experience a surplus (cash-rich units) to business units in deficit (cash-poor units) to avoid financial distress. The lower the risk of a company, the greater the opportunity for the company to increase its debt capacity (Amihud \& Lev, 1981; Franco, Urcan, \& Vasvari, 2010; Hann, Ogneva, \& Ozbas, 2013). 
Further, Jensen and Meckling (1976) explain that a company will be bankrupt when it cannot meet its financial obligations to its creditors. A company that has a high level of bankruptcy risk finds it difficult to increase capital. Therefore, a merger strategy is used to pay off the company's liabilities during financial difficulties. Ji, Mauer, and Zhang (2019) analyze how effects of the diversification relation between managerial entrenchment and leverage. They use the managerial entrenchment hypothesis and creditor alignment hypothesis in predicting their models. There are two different predictive theories between leverage and governance. The first prediction is that managers will choose lower leverage, and leverage increases as the firm improve. Another opinion states that the alignment of creditors expects managers to have high leverage, and leverage will decrease along with improving governance

Research from Ji et al. (2019) found that diversification discounts Only occurs in leveraged firms and conflicts of interest between managers and shareholders over corporate risk-taking; this finding supports previous research from Ammann et al. (2012). Interestingly, diversification discounts occur as a result of poor corporate governance. Poor corporate governance and high levels of diversification were the two main causes of Enron Corporation's bankruptcy in 2001 (Shanker, 2012). Xuan and Nguyen (2018) describe two sides of diversification that can substantially create opportunities for companies to grow and carry a higher risk of bankruptcy. A manager who engages in moral hazard may choose to diversify based on their personal interests. Therefore, companies must be careful in determining the strategy.

The study looked at the relationship between diversification strategies and debt levels. Further, we investigate whether corporate governance will decrease or increases the leverage when companies become more diversified. Our findings show that leverage increases due to implementing good governance in diversified companies. The results of this study found evidence of company diversification in developing countries, such as Indonesia, in addition to the literature review.

\section{LITERATURE REVIEW AND HYPOTHESES DEVELOPMENT}

\section{Corporate Diversification and Leverage}

Since Modigliani and Miller (1958) introduced the potential benefits of tax savings, the optimal capital structure may consist of 100 percent debt in the absence of bankruptcy costs. However, the company can fall into bankruptcy and punishment if it cannot fulfill its debt obligations. (Butt, 2020). Literature review explains that diversified companies have higher leverage than stand-alone companies (Kuppuswamy \& Villalonga, 2016; Monteforte \& Stagliano, 2015; Singh, Davidson, \& Suchard, 2003).

Lewellen (1971) introduced the addition of debt capacity with a co-insurance effect. The way for companies to reduce the volatility of the company's cash flows is to make a corporate group. It thereby has a lower probability of default as long as the income streams of each business entity in the diversified firms are less than perfectly positively correlated. Diversified companies have a lower cost of capital than comparable single-segment companies. Where the found are consistent with the theory of co-insurance. (Hann, Ogneva, and Ozbas, 2013).They further find that the less correlated the firm's segment cash flows, the higher the benefit from diversification in reducing a firm's cost of capital. 
Diversified firms will realize the opportunity to increase debt levels to obtain higher tax benefits (Jahera \& Lloyd, 1996; Hoang, Nguyen, \& Zhang, 2021) and increase operational efficiency with better monitoring activities (Jensen \& Meckling, 1976). It is also supported by Teruel, Solano, \& Ballesta (2014), firms that produce more stable revenue and lower earnings volatility have higher debt capacity. In addition, Mansi and Reeb (2002) show a consistent finding that a diversified firm's debt capacity is higher than an undiversified firm even at the same level Cash flow volatility.

Another concept that might explain the greater use of leverage in multi-segment firms is based on agency conflict between a company's management. Ji et al. (2019) explain that agency in diversified companies encourages the use of large leverage sourced from the interests of managers. Therefore, based on co-insurance, agency view, and previous empirical findings, this study assumes a positive relationship between leverage and diversification.

\section{$\mathrm{H}_{1}$ : Corporate diversification increases a firm's leverage}

\section{Corporate Diversification, Good Governance, and Leverage}

The role of corporate governance strongly influences the increase in the company's financial performance. The OECD (2015) explains that the goal in building a good company is to build good corporate governance. Good corporate governance can be reflected in transparency, accountability, integrity, financial stability, and trust. Company management, shareholders, board of commissioners, and other stakeholders have an essential role in the creation of corporate governance. It also provides a structure within which the company's vision and mission are defined.

We include governance in this study to consider its effect on diversification and leverage relationships. Claessens and Yurtoglu (2013) findings that financial access will be easier to obtain if companies can build a good governance system. However, based on agency theory, Xuan and Nguyen (2018) show that independent directors play an essential role in managers' decision-making, showing a negative effect between board composition and diversification.

There is a widespread belief that debt is a commitment tool to minimize agency costs in companies with weak governance (Vijayakumaran, 2019). Agency conflicts between shareholders and managers are often cited as contributing to the loss of value from diversification (Anderson et al., 2000). There is a possibility for opportunistic managerial behavior in diversification decisions, such as increasing compensation or reducing the risk of losing their job.

Hund, Monk, and Tice (2010) found that the emergence of diversification discounts results from agency problems such as; managerial overconfidence, managerial arrogance, and managerial attempts to protect the value of their human capital. Managers have the personal advantage of managing a larger company (Stulz, 1990). As a result, managers can use diversification to strengthen themselves and extract rent from shareholders by making manager-specific investments (Shleifer \& Vishny, 1992). Therefore, the managerial entrenchment hypothesis predicts that entrenched managers will choose lower leverage, and leverage will increase as governance improves (Ji et al., 2019). Therefore, Ammann et al. (2012) show that good corporate governance impacts creating more value in a diversification strategy. They believe that conglomerate discounts are the result of agency problems. 
This study assumes that diversification increases a firm's leverage by reducing a firm's risk. To what extent it could be increased might be determined by how the firm is governed. John and Litov's (2010) empirical findings show that firms with bad governance use more leverage than firms with good governance. Based on these findings, Ji et al. (2019) predict that leverage will decrease as governance improves. We use the same logic in developing the hypothesis as follows:

$\mathrm{H}_{2}$ : The better the governance, the lower the effect of corporate diversification in increasing a firm's leverage.

\section{METHODOLOGY}

\section{Data Description}

Our sample is manufacturing companies listed on the Indonesian Stock Exchange (IDX) over 2014-2020 with at least two business segments. Sample selection begins by classifying a firm, whether a single or multi-segment company, through segmental reporting disclosed on financial or annual reports. The final sample that meets the criteria is 43 firms over seven years, with 301 observations. The data is collected from audited consolidated financial statements. However, due to missing data in the Herfindahl index, the sample became only 297 observations.

\section{Leverage}

Based on Ji et al. (2019), our dependent variable is the firm's leverage estimated based on debt to total assets and debt to equity ratio. This variable reflects the amount of debt that companies include in their capital structure, indicating how much benefit companies get from diversification strategy on reducing their risk. We run each regression model twice based on each proxy to compare how consistent are the regression results.

\section{Diversification Strategy}

Our main independent variable is diversification strategy. We follow prior research in measuring corporate diversification based on Berger and Ofek (1995), Denis, Denis, and Yost (2002), Mansi and Reeb (2002), and Franco et al. (2010) by using two alternative proxies;

1. Number of business segments, and

2. Herfindahl Index (HI) is calculated from the sum of squares of sales for each segment divided by the square of the company's total sales. Nevertheless, following Franco et al. (2010) and Xuan and Nguyen (2018), we deduct the Herfindahl Index by one so that indices closer to 1 indicate a higher level of diversification. This formula is also known as the Modified Berry-Herfindahl Index that Montgomery suggested (1982), where Pi is the proportion of the segment i's sales to total sales. The closer the index to 1 , the more diversified the firm is. A higher HHI value indicates greater sales concentration which means a lower level of diversification, as the question 1.

$$
\text { diversification }=1-\frac{\sum P_{i}^{2}}{\left(\sum P_{i}\right)^{\prime}}
$$




\section{Corporate Governance}

Several empirical studies state that the implementation of efficient investment decisions can address agency problems in corporate governance mechanisms. (Chen \& Chen, 2012). Therefore, we expect lower leverage for diversified firms with good governance mechanisms measured through board independence and ownership structure. In addition, the findings of previous studies demonstrate the importance of board independence in managing firms effectively, increasing their value, and preventing selfserving actions from managers (Anderson et al., 2000; Ji et al., 2019; Xuan \& Nguyen, 2018). ).

Corporate governance is getting better the greater the independence of the board. We measure board independence by the fraction of independent directors on the board. We define independent directors as directors who do not own shares in the company and are not affiliated with any executive board or board of directors.

Furthermore, monitoring and disciplining managers in institutions require the role of investors (Elyasiani \& Jia, 2010). We measure institutional ownership by the percentage of shares held by institutions, including private and public companies. Increasing the number of non-executive directors outside the composition of the board will lead to good governance. (Castaner \& Kavadis, 2013).

\section{Control Variables}

To minimize omitted variable bias and isolate the model from other influences, we have also controlled several firm-specific factors that may affect the financial structure. Those variables consist of firm size, profitability ratio, and asset tangibility (Butt, 2020; Ji et al., 2019; Xuan \& Nguyen, 2018). Firm size is defined as the natural logarithm of total assets. Larger firms have a lower cost of information, experience a better reputation in debt markets. Therefore, they are predicted to have more debt in their capital structure (Butt, 2020).

Pecking order theory suggests that profitable firms prefer internal financing. It offers a lower cost of capital due to a lower level of information asymmetry and, therefore, has better access to capital markets (Cappa, Cetrini, \& Oriani, 2020; Myers \& Majluf, 1984). On the other hand, trade-off theory suggests that more profitable companies would have more reasons to seek a tax benefit from debt. Therefore, firms' profitability is included in our model, proxied by the return on assets (ROA) (Teruel \& Solano, 2005).

Finally, big firms tend to hold more tangible assets used as collateral for bank loans, reflected in a greater indebtedness (Coleman, Cotei, \& Farhat, 2016). Tangible assets are measured by the ratio of fixed assets to total assets, naturally serve as collateral, and are often associated with increased leverage (Frank \& Goyal, 2002).

\section{Model Specification}

Multiple regression analysis is undertaken to investigate the effect of diversification strategy on a firm's leverage using Stata 13. Not only pooled OLS but OLS with robust standard errors and generalized least squares (GLS) was also conducted to check the stability of the result. Autocorrelation and heteroscedasticity are the central issues in panel data that might increase the error of estimation to increase the efficiency of the model 
estimation, the error needs to be minimized. Therefore, OLS with robust standard errors and GLS is attempted to reduce the error.

This study has three models in explaining the effect of diversification strategy on a firm's leverage. The first model is used to test only the impact of diversification on a firm's leverage. The second and third models are formulated by adding two interaction variables: institutional ownership and independent board, as shown in equations 2, 3, and 4.

\section{Model I}

LEVit $=\alpha+\beta_{1} \mathrm{DIV}_{\text {it }}+\beta_{2} \mathrm{ROA}_{\mathrm{it}}-\beta_{3} \mathrm{TANG}_{\mathrm{it}}+\beta_{4} \mathrm{SIZEit}+\varepsilon_{\mathrm{it}}$

Model II

LEVit $=\alpha+\beta_{1} \mathrm{DIV}_{i t}-\beta_{2} \mathrm{IO}_{i t}-\beta_{3}\left(\mathrm{DIV}^{*} \mathrm{IO}\right)_{i \mathrm{it}}+\beta_{4} \mathrm{ROA}_{\mathrm{it}}-\beta_{5} \mathrm{TANG}_{\mathrm{it}}+\beta_{6} \mathrm{SIZEit}+\varepsilon_{i t}$

Model III

LEVit $=\alpha+\beta_{1}$ DIV $_{\text {it }}-\beta_{2} \mathrm{ID}_{\text {it }}-\beta_{3}\left(\mathrm{DIV}{ }^{*} \mathrm{ID}\right)_{\mathrm{it}}+\beta_{4} \mathrm{ROA}_{i t}-\beta_{5} \mathrm{TANG}_{i t}+\beta_{6} \mathrm{SIZEit}+\varepsilon_{\mathrm{i}}$

LEV represents the level of leverage; DIV is measuring diversification strategy; ROA is the return on assets as a measure for profitability; TANG is the number of tangible assets; IO stands for institutional ownership and; ID measuring the ratio of independent directors on board composition.

\section{RESULTS AND DISCUSSION}

\section{Descriptive Statistics}

Table 1 reports the descriptive statistics for the dependent and independent variables introduced in our empirical model. We provide evidence that, on average, diversified firms in Indonesia have three business segments that are not very heterogeneous. It is supported by the Herfindahl index that shows a consistent finding with an average score of only 0.41 , and the highest score is 0.78 .

Table 1. Descriptive Statistic

\begin{tabular}{lrrrrr}
\hline \multicolumn{1}{c}{ Variable } & Obs & Mean & Std. Dev. & Min & Max \\
\hline 1-Herfindahl Index (DIV) & 297 & 0.41 & 0.20 & 0.00 & 0.78 \\
Number of Segments (DIV) & 297 & 3.04 & 1.15 & 2.00 & 7.00 \\
Institutional Ownership (IO) & 297 & 0.63 & 0.25 & 0.00 & 0.98 \\
Ratio of Independent Directors (ID) & 297 & 0.38 & 0.12 & 0.00 & 0.80 \\
ROA & 297 & 0.07 & 0.11 & -0.40 & 0.92 \\
TANGIB & 297 & 0.44 & 0.16 & 0.16 & 0.81 \\
SIZE & 297 & 28.72 & 1.55 & 25.33 & 32.73 \\
DER & 297 & 1.01 & 1.00 & 0.05 & 9.32 \\
Debt to Total Assets & 297 & 0.41 & 0.20 & 0.02 & 1.06 \\
\hline
\end{tabular}


The debt to total assets ratio has an average equal to $41 \%$ with a standard deviation equal to $19 \%$ and varies between $2 \%$ to $106 \%$. In terms of institutional ownership, the data shows that, on average, more than $60 \%$ of stock ownership belongs to institutional as controlling shareholders. Further, the ratio of independent directors on the board is around $37 \%$ on average. Interestingly, most of the companies' assets are intangible which the average tangible assets are $44 \%$. Further, the correlation coefficients for variables are observed in table 2 .

Table 2. Pearson Correlations

\begin{tabular}{llllllllll}
\hline & 1 & 2 & 3 & 4 & 5 & 6 & 7 & 8 & 9 \\
\hline 1 Herfindahl Index & 1 & & & & & & & & \\
2 Number of Segments & $0.44^{* * *}$ & 1 & & & & & & & \\
3 Institutional Own. & -0.08 & -0.01 & 1 & & & & & & \\
4 Independent Directors & 0.09 & $0.18^{* * *}$ & 0.03 & 1 & & & & & \\
5 ROA & -0.00 & -0.01 & 0.03 & $0.33^{* * *}$ & 1 & & & & \\
6 TANGIB & -0.06 & $-0.07^{*}$ & $0.11^{*}$ & 0.08 & -0.06 & 1 & & & \\
7 SIZE & 0.03 & $0.25^{* * *}$ & -0.06 & $0.28^{* * *}$ & $0.28^{* * *}$ & $0.33^{* * *}$ & 1 & & \\
8 DER & $0.19^{* * *}$ & $0.11^{*}$ & -0.00 & $0.14^{* *}$ & -0.09 & 0.06 & -0.02 & 1 & \\
9 Debt to Total Assets & $0.13^{* *}$ & $0.15^{* *}$ & -0.05 & $0.11^{*}$ & $-0.14^{*}$ & 0.04 & -0.08 & $0.72^{* * *}$ & 1 \\
\hline
\end{tabular}

\section{Diversification Impact on Leverage}

Tables 3 and 4 depict the empirical results of regression estimates of the Herfindahl index and the number of segments effects, respectively, on debt level. Model 1 is analyzed based on pooled ordinary least squares (OLS), model 2 is regressed based on OLS with robust standard errors, and model 3 is based on the generalized least squares (GLS) method.

Both the Herfindahl index and the number of segments significantly affect increasing a firm's leverage. It indicates that the more diversified the firms, the higher leverage they have. This result supports the first hypothesis and the previous research findings (La Rocca et al., 2009; Singh et al., 2003; Qureshi, Akhtar, \& Imdadullah, 2012). The coefficients of the explanatory variables keep the same sign for all models, which confirms the strength of the results.

However, it shows the difference in the level of significance between both proxies. Herfindahl index indicates a higher magnitude on debt to equity ratio, whereas segment numbers significantly impact debt to total assets. This finding supports the theoretical perspective, where a positive relationship supports the behavioral view of capital structure and the co-insurance effect associated with decisions and strategies. (Barton \& Gordon, 1988; Cappa et al., 2020). 
Table 3. Effects of Diversification on Leverage

\begin{tabular}{|c|c|c|c|c|c|c|}
\hline & \multicolumn{3}{|c|}{ Debt to Equity Ratio } & \multicolumn{3}{|c|}{ Debt to Total Assets } \\
\hline & (1) & (2) & (3) & (1) & $(2)$ & (3) \\
\hline \multirow[t]{2}{*}{ 1-Herfindahl Index } & $0.972^{* * *}$ & $0.972^{* * *}$ & $0.972^{* * *}$ & $0.132^{* *}$ & $0.132^{* *}$ & $0.132^{* *}$ \\
\hline & $(0.282)$ & $(0.294)$ & $(0.280)$ & $(0.056)$ & $(0.060)$ & $(0.055)$ \\
\hline \multirow[t]{2}{*}{$\mathrm{ROA}$} & -0.720 & -0.720 & -0.720 & $-0.215^{\star *}$ & -0.215 & $-0.215^{\star *}$ \\
\hline & $(0.549)$ & $(0.772)$ & $(0.545)$ & $(0.109)$ & $(0.170)$ & $(0.108)$ \\
\hline \multirow[t]{2}{*}{ TANGIB } & 0.494 & 0.494 & 0.494 & 0.075 & 0.075 & 0.075 \\
\hline & $(0.383)$ & $(0.463)$ & $(0.380)$ & $(0.076)$ & $(0.082)$ & $(0.075)$ \\
\hline \multirow[t]{2}{*}{ SIZE } & -0.018 & -0.018 & -0.018 & -0.009 & -0.009 & -0.009 \\
\hline & $(0.041)$ & $(0.028)$ & $(0.041)$ & $(0.008)$ & $(0.007)$ & $(0.008)$ \\
\hline \multirow[t]{2}{*}{ Constant } & 0.955 & 0.955 & 0.955 & $0.607^{* * *}$ & $0.607^{* * *}$ & $0.607^{* * *}$ \\
\hline & $(1.126)$ & $(0.752)$ & $(1.117)$ & $(0.223)$ & $(0.191)$ & $(0.221)$ \\
\hline Observations & 297 & 297 & 297 & 297 & 297 & 297 \\
\hline R-squared & 0.051 & 0.051 & & 0.043 & 0.043 & \\
\hline
\end{tabular}

Standard errors in parentheses

*** $\mathrm{p}<0.01,{ }^{* *} \mathrm{p}<0.05,{ }^{*} \mathrm{p}<0.10$

Table 3 presents the regression results of corporate diversification (proxied by the Herfindahl Index) on a firm's leverage. The model is analyzed based on three regression methods, pooled ordinary least squares (OLS) (1), OLS with robust standard errors (2), and generalized least squares (GLS) (3).

Table 4. Effects of Diversification on Leverage

\begin{tabular}{lrrrrrr}
\hline & \multicolumn{3}{c}{ Debt to Equity Ratio } & \multicolumn{3}{c}{ Debt to Total Assets } \\
\cline { 2 - 7 } Segments number & $(1)$ & $(2)$ & $(3)$ & $(1)$ & $(2)$ & $(3)$ \\
& $0.115^{* *}$ & $0.115^{*}$ & $0.115^{* *}$ & $0.031^{* * *}$ & $0.031^{* * *}$ & $0.031^{* * *}$ \\
ROA & $(0.053)$ & $(0.061)$ & $(0.053)$ & $(0.010)$ & $(0.009)$ & $(0.010)$ \\
& -0.633 & -0.633 & -0.633 & $-0.184^{*}$ & -0.184 & $-0.184^{*}$ \\
TANGIB & $(0.559)$ & $(0.736)$ & $(0.555)$ & $(0.109)$ & $(0.167)$ & $(0.108)$ \\
& 0.547 & 0.547 & 0.547 & 0.104 & 0.104 & 0.104 \\
SIZE & $(0.393)$ & $(0.448)$ & $(0.390)$ & $(0.077)$ & $(0.082)$ & $(0.076)$ \\
& -0.039 & -0.039 & -0.039 & $-0.016^{*}$ & $-0.016^{* *}$ & $-0.016^{*}$ \\
Constant & $(0.044)$ & $(0.034)$ & $(0.044)$ & $(0.009)$ & $(0.007)$ & $(0.008)$ \\
& 1.573 & $1.573^{*}$ & 1.573 & $0.749^{* * *}$ & $0.749^{* * *}$ & $0.749^{* * *}$ \\
Observations & $(1.155)$ & $(0.860)$ & $(1.145)$ & $(0.225)$ & $(0.187)$ & $(0.223)$ \\
R-squared & 297 & 297 & 297 & 297 & 297 & 297 \\
\hline
\end{tabular}

Standard errors in parentheses

*** $\mathrm{p}<0.01,{ }^{* *} \mathrm{p}<0.05,{ }^{*} \mathrm{p}<0.10$

Table 4 presents the regression results of corporate diversification (proxied by a number of the segment) on a firm's leverage. The model is analyzed based on three regression methods, pooled ordinary least squares (OLS) (1), OLS with robust standard errors (2), and generalized least squares (GLS) (3). 


\section{Diversification Strategy, Corporate Governance, and Firm's Leverage}

To further examine the impact of diversification strategy on a firm's leverage, we perform multivariate regression analyses by considering governance issue as the moderating variable as provided in table 5-8. In Tables 5 and 6, we examine the relationship between diversification and institutional ownership on leverage. The first one is measured based on the Herfindahl index and the latest based on segments number. Tables 7 and 8 provide similar results. However, the governance variable is estimated based on board composition.

We expect that the better the governance, the lower the effect of corporate diversification in increasing a firm's leverage. We believe that leverage will decrease as governance improves due to the alignment of interests between shareholders and managers.

The moderated regression analysis of corporate governance also shows that both institutional ownership (Tables 5 \& 6) and board composition (Tables 7 \& 8) have a significant effect but in a different direction. The institutional ownership supports the hypothesis, whereas the ratio of the independent board shows the opposite direction. The coefficient of interaction between institutional ownership and diversification on debt to total asset in all models is significantly positive. In contrast, the debt to equity ratio only shows a significant impact when diversification is measured based on the Herfindahl index. Our findings suggest that a higher level of institutional ownership will lead to more effective monitoring resulting in a lower debt ratio in diversified firms.

On the other hand, an independent director is significantly positive in all models when diversification is measured based on the Herfindahl index (table 7), whereas when a number of segments measure it, none of the models shows a significant impact. These findings indicate that independent boards have a partial effect on moderating the relationship between diversification and leverage. As the coefficient of interaction variable is positive, it shows that diversified firms with a higher percentage of independent directors have a higher debt ratio which contrasting the previous results. These findings align with Florackis and Ozkan (2009) and Butt (2020), who found that companies that actively seek optimal capital structures that match profits are companies with good governance structures. Partially, we believe that institutional ownership has a significant effect on governance compared to independent boards that do not think about the future of the company. They may have a more significant influence on corporate governance than independent boards because they do not have any interest in the company's future.

Table 5. Effects of Diversification and Institutional Ownership on Leverage

\begin{tabular}{lrrrrrr}
\hline & \multicolumn{3}{c}{ Debt to Equity Ratio } & \multicolumn{3}{c}{ Debt to Total Assets } \\
\cline { 2 - 7 } & $(1)$ & $(2)$ & $(3)$ & $(1)$ & $(2)$ & $(3)$ \\
\hline 1-Herfindahl Index (DIV) & $2.426^{* * *}$ & $2.426^{* * *}$ & $2.426^{* * *}$ & $0.512^{* * *}$ & $0.512^{* * *}$ & $0.512^{* * *}$ \\
& $(0.876)$ & $(0.696)$ & $(0.865)$ & $(0.173)$ & $(0.174)$ & $(0.171)$ \\
Institutional Ownership (IO) & 1.006 & $1.006^{*}$ & $1.006^{*}$ & $0.225^{*}$ & $0.225^{*}$ & $0.225^{*}$ \\
& $(0.614)$ & $(0.553)$ & $(0.607)$ & $(0.121)$ & $(0.135)$ & $(0.120)$ \\
& $-2.202^{*}$ & $-2.202^{*}$ & $-2.202^{*}$ & $-0.579^{* *}$ & $-0.579^{* *}$ & $-0.579^{* *}$ \\
\hline
\end{tabular}




\begin{tabular}{lrrrrrr}
\hline & \multicolumn{3}{c}{ Debt to Equity Ratio } & \multicolumn{3}{c}{ Debt to Total Assets } \\
\cline { 2 - 7 } & $(1)$ & $(2)$ & $(3)$ & $(1)$ & $(2)$ & $(3)$ \\
\hline \multirow{3}{*}{ ROA } & $(1.256)$ & $(1.223)$ & $(1.241)$ & $(0.248)$ & $(0.264)$ & $(0.245)$ \\
& -0.679 & -0.679 & -0.679 & $-0.197^{*}$ & -0.197 & $-0.197^{*}$ \\
TANGIB & $(0.550)$ & $(0.774)$ & $(0.544)$ & $(0.108)$ & $(0.165)$ & $(0.107)$ \\
& 0.560 & 0.560 & 0.560 & 0.102 & 0.102 & 0.102 \\
SIZE & $(0.389)$ & $(0.482)$ & $(0.384)$ & $(0.077)$ & $(0.082)$ & $(0.076)$ \\
& -0.026 & -0.026 & -0.026 & -0.012 & $-0.012^{*}$ & -0.012 \\
Constant & $(0.042)$ & $(0.027)$ & $(0.041)$ & $(0.008)$ & $(0.007)$ & $(0.008)$ \\
& 0.492 & 0.492 & 0.492 & $0.532^{* *}$ & $0.532^{* * *}$ & $0.532^{* *}$ \\
& $(1.185)$ & $(0.815)$ & $(1.171)$ & $(0.234)$ & $(0.205)$ & $(0.231)$ \\
Observations & & & & & & \\
R-squared & 297 & 297 & 297 & 297 & 297 & 297 \\
Standard errors in parentheses & 0.061 & 0.061 & & 0.063 & 0.063 & \\
\hline *** $\mathrm{p}<0.01,{ }^{* *} \mathrm{p}<0.05,{ }^{*} \mathrm{p}<0.10$ & & & & & & \\
\hline
\end{tabular}

Table 5 presents the regression results of corporate diversification (proxied by the Herfindahl Index) and the ratio of independent directors on a firm's leverage. The model is analyzed based on three regression methods, pooled ordinary least squares (OLS) (1), OLS with robust standard errors (2), and generalized least squares (GLS) (3).

Table 6. Effects of Diversification and Institutional Ownership on Leverage

\begin{tabular}{lrrrrrr}
\hline & \multicolumn{3}{c}{ Debt to Equity Ratio } & \multicolumn{3}{c}{ Debt to Total Assets } \\
\cline { 2 - 7 } & $(1)$ & $(2)$ & $(3)$ & $(1)$ & $(2)$ & $(3)$ \\
\hline Segments number (DIV) & $0.373^{* *}$ & $0.373^{* *}$ & $0.373^{* *}$ & $0.116^{* * *}$ & $0.116^{* * *}$ & $0.116^{* * *}$ \\
& $(0.179)$ & $(0.161)$ & $(0.177)$ & $(0.035)$ & $(0.028)$ & $(0.034)$ \\
Institutional Ownership (IO) & 1.042 & 1.042 & 1.042 & $0.311^{* *}$ & $0.311^{* *}$ & $0.311^{* *}$ \\
& $(0.770)$ & $(0.802)$ & $(0.761)$ & $(0.148)$ & $(0.135)$ & $(0.147)$ \\
DIV*IO & -0.399 & -0.399 & -0.399 & $-0.130^{* *}$ & $-0.130^{* * *}$ & $-0.130^{* * *}$ \\
& $(0.265)$ & $(0.313)$ & $(0.262)$ & $(0.051)$ & $(0.044)$ & $(0.051)$ \\
ROA & -0.595 & -0.595 & -0.595 & -0.166 & -0.166 & -0.166 \\
& $(0.561)$ & $(0.752)$ & $(0.555)$ & $(0.108)$ & $(0.165)$ & $(0.107)$ \\
TANGIB & 0.545 & 0.545 & 0.545 & 0.111 & 0.111 & 0.111 \\
& $(0.398)$ & $(0.449)$ & $(0.393)$ & $(0.077)$ & $(0.080)$ & $(0.076)$ \\
SIZE & -0.040 & -0.040 & -0.040 & $-0.017^{* *}$ & $-0.017^{* *}$ & $-0.017^{* *}$ \\
& $(0.044)$ & $(0.033)$ & $(0.044)$ & $(0.009)$ & $(0.008)$ & $(0.008)$ \\
Constant & 0.942 & 0.942 & 0.942 & $0.578^{* *}$ & $0.578^{* * *}$ & $0.578^{* *}$ \\
& $(1.276)$ & $(1.183)$ & $(1.261)$ & $(0.246)$ & $(0.219)$ & $(0.243)$ \\
Observations & 297 & 297 & 297 & 297 & 297 & 297 \\
R-squared & 0.035 & 0.035 & & 0.079 & 0.079 & \\
\hline
\end{tabular}

Standard errors in parentheses

*** $\mathrm{p}<0.01,{ }^{* *} \mathrm{p}<0.05,{ }^{*} \mathrm{p}<0.10$

Table 6 presents the regression results of corporate diversification (proxied by a number of the segment) and the ratio of independent directors on the firm's leverage. The model is analyzed based on three regression methods, pooled ordinary least squares (OLS) (1), OLS with robust standard errors (2), and generalized least squares (GLS) (3). 
Table 7. Effects of Diversification and Board Composition on Leverage

\begin{tabular}{lrrrrrr}
\hline & \multicolumn{3}{c}{ Debt to Equity Ratio } & \multicolumn{3}{c}{ Debt to Total Assets } \\
\cline { 2 - 7 } & $(1)$ & $(2)$ & $(3)$ & $(1)$ & $(2)$ & $(3)$ \\
\hline 1-Herfindahl Index (DIV) & $-2.588^{* * *}$ & -2.588 & $-2.588^{* * *}$ & $-0.331^{*}$ & -0.331 & $-0.331^{*}$ \\
& $(0.877)$ & $(1.690)$ & $(0.867)$ & $(0.177)$ & $(0.217)$ & $(0.175)$ \\
Independent Directors (ID) & $-1.616^{*}$ & -1.616 & $-1.616^{*}$ & -0.103 & -0.103 & -0.103 \\
& $(0.907)$ & $(1.218)$ & $(0.896)$ & $(0.183)$ & $(0.234)$ & $(0.181)$ \\
DIV*ID & $9.267^{* * *}$ & $9.267^{* *}$ & $9.267^{* * *}$ & $1.192^{* * *}$ & $1.192^{* *}$ & $1.192^{* * *}$ \\
& $(2.219)$ & $(4.662)$ & $(2.192)$ & $(0.447)$ & $(0.530)$ & $(0.442)$ \\
ROA & $-1.443^{* * *}$ & -1.443 & $-1.443^{* * *}$ & $-0.338^{* * *}$ & $-0.338^{*}$ & $-0.338^{* * *}$ \\
& $(0.552)$ & $(0.968)$ & $(0.546)$ & $(0.111)$ & $(0.181)$ & $(0.110)$ \\
TANGIB & 0.295 & 0.295 & 0.295 & 0.047 & 0.047 & 0.047 \\
& $(0.370)$ & $(0.493)$ & $(0.366)$ & $(0.075)$ & $(0.084)$ & $(0.074)$ \\
SIZE & -0.030 & -0.030 & -0.030 & -0.012 & -0.012 & -0.012 \\
& $(0.040)$ & $(0.034)$ & $(0.040)$ & $(0.008)$ & $(0.008)$ & $(0.008)$ \\
Constant & $2.047^{*}$ & $2.047^{* *}$ & $2.047^{*}$ & $0.756^{* * *}$ & $0.756^{* * *}$ & $0.756^{* * *}$ \\
& $(1.107)$ & $(1.017)$ & $(1.094)$ & $(0.223)$ & $(0.199)$ & $(0.220)$ \\
Observations & 297 & 297 & 297 & 297 & 297 & 297 \\
R-squared & 0.130 & 0.130 & & 0.092 & 0.092 & \\
\hline
\end{tabular}

Standard errors in parentheses

${ }^{* * *} \mathrm{p}<0.01,{ }^{* *} \mathrm{p}<0.05,{ }^{*} \mathrm{p}<0.10$

Table 7 presents the regression results of corporate diversification (proxied by the Herfindahl Index) and the ratio of independent directors on a firm's leverage. The model is analyzed based on three regression methods, pooled ordinary least squares (OLS) (1), OLS with robust standard errors (2), and generalized least squares (GLS) (3).

Table 8. Effects of Diversification and Board Composition on Leverage

\begin{tabular}{lrrrrrr}
\hline & \multicolumn{3}{c}{ Debt to Equity Ratio } & \multicolumn{3}{c}{ Debt to Total Assets } \\
\cline { 2 - 7 } & $(1)$ & $(2)$ & $(3)$ & $(1)$ & $(2)$ & $(3)$ \\
\hline Segments number (DIV) & 0.037 & 0.037 & 0.037 & 0.049 & 0.049 & 0.049 \\
& $(0.186)$ & $(0.298)$ & $(0.183)$ & $(0.036)$ & $(0.035)$ & $(0.036)$ \\
Independent Directors (ID) $)$ & 1.194 & 1.194 & 1.194 & $0.417^{*}$ & 0.417 & $0.417^{*}$ \\
& $(1.255)$ & $(1.759)$ & $(1.241)$ & $(0.245)$ & $(0.304)$ & $(0.242)$ \\
DIV*ID & 0.124 & 0.124 & 0.124 & -0.050 & -0.050 & -0.050 \\
& $(0.413)$ & $(0.753)$ & $(0.409)$ & $(0.081)$ & $(0.081)$ & $(0.080)$ \\
ROA & $-1.088^{*}$ & -1.088 & $-1.088^{*}$ & $-0.280^{* *}$ & -0.280 & $-0.280^{* *}$ \\
& $(0.583)$ & $(0.780)$ & $(0.576)$ & $(0.114)$ & $(0.171)$ & $(0.112)$ \\
TANGIB & 0.480 & 0.480 & 0.480 & 0.094 & 0.094 & 0.094 \\
& $(0.390)$ & $(0.462)$ & $(0.385)$ & $(0.076)$ & $(0.083)$ & $(0.075)$ \\
SIZE & -0.056 & -0.056 & -0.056 & $-0.019^{* *}$ & $-0.019^{* *}$ & $-0.019^{* *}$ \\
& $(0.044)$ & $(0.040)$ & $(0.043)$ & $(0.009)$ & $(0.008)$ & $(0.008)$ \\
Constant & 1.756 & 1.756 & 1.756 & $0.692^{* * *}$ & $0.692^{* * *}$ & $0.692^{* * *}$ \\
& $(1.251)$ & $(1.507)$ & $(1.236)$ & $(0.244)$ & $(0.228)$ & $(0.241)$ \\
Observations & \multicolumn{7}{c}{} & & & & \\
R-squared & 297 & 297 & 297 & 297 & 297 & 297 \\
\hline Standard errors in parantheses $*^{* * *} \mathrm{p}<0$ & $0.051^{* *} \mathrm{p}<0.05{ }^{*} \mathrm{p}<0.10$ & & & & \\
\hline
\end{tabular}

Standard errors in parentheses ; ${ }^{* * *} \mathrm{p}<0.01,{ }^{* *} \mathrm{p}<0.05,{ }^{*} \mathrm{p}<0.10$

Table 8 presents the regression results of corporate diversification (proxied by a number of the segment) and the ratio of independent directors on the firm's leverage. The model is 
analyzed based on three regression methods, pooled ordinary least squares (OLS) (1), OLS with robust standard errors (2), and generalized least squares (GLS) (3).

\section{CONCLUSION}

This article examines whether diversification strategies are related to firm capital structure decisions. The number of samples in this study amounted to 297 companies operating in Indonesia for seven years between 2014 and 2020, we see from the impact of diversification on debt ratios. The results of this study indicate a positive relationship between diversification and leverage. This positive effect implies that the more diversified a company is, the higher the leverage ratio. These results have considered three different regression models, namely pooled least squares, OLS with solid standard errors, and generalized least squares (GLS).

The findings of this study can assist academic researchers and managers in making decisions for firms about diversification options and their potential effects on target leverage. This paper begins by stating that diversified companies will use more debt than single segment companies because they have a lower level of risk. We identify that good corporate governance mechanisms may be relevant in strengthening or weakening the effect of diversification on corporate leverage.

The results show two main implications. First, the positive relationship between diversification and leverage indicates that higher levels of agency costs in diversified firms can be reduced by adding more debt to the firm's capital structure. Second, firms with high levels of institutional ownership should be more careful in approving diversification projects because they exhibit lower levels of leverage, which leads managers to overinvestment strategies. Finally, it is important to have a strong governance structure in a diversified company to control the behavior of managers and ensure they act only in the best interests of shareholders.

Good governance significantly strengthens the effect of diversification on corporate leverage. Diversified companies with better governance have higher leverage than diversified companies with poorer governance.

\section{REFERENCES}

Ahuja, G., \& Novelli, E. (2017). Redirecting research efforts on the diversificationperformance linkage: The search for synergy. Academy of Management Annals, 11(1), 342-390. https:// doi.org/10.5465/annals.2014.0079

Amihud, Y., \& Lev, B. (1981). Risk reduction as a managerial motive for conglomerate mergers. Bell Journal of Economics, 12(2), 605-6017. https://doi.org/10.2307/3003575

Ammann, M., Hoechle, D., \& Schmid, M. (2012). Is there really no conglomerate discount?. Journal of Business Finance and Accounting, 39(1-2), 264-288. https://doi.org/10.1111/j.1468-5957.2011.02261.x

Anderson, R. C., Bates, T. W., Bizjak, J. M., \& Michael, M. L. (2000). Corporate governance and firm diversification. Financial Management, 29(1), 5-22. https:// doi.org/10.2307/3666358 
Barton, S. L., \& Gordon, P. J. (1988). Corporate strategy and capital structure. Strategic Management Journal, 9(6), 623-632. http:/ / dx.doi.org/10.1002/smj.4250090608

Berger, P. G., \& Ofek, E. (1995). Diversification's effect on firm value. Journal of Financial Economics, 37(1), 39-65. https:/ / doi.org/10.1016/0304-405(94)00798-6

Berger, A. N., Hasan, I., \& Zhou, M. (2010). The effects of focus versus diversification on bank performance: Evidence from Chinese banks. Journal of Banking \& Finance, 34(7), 1417-1435. http:/ / dx.doi.org/10.1016/j.jbankfin.2010.01.010.

Butt, U. (2020). Profits, financial leverage and corporate governance. International Journal of Managerial Finance, 16(2), 203-223. https:/ / doi.org/10.1108/IJMF-03-2019-0091

Cappa, F., Cetrini, G., \& Oriani, R. (2020). The impact of corporate strategy on capital structure: Evidence from Italian listed firms. Quarterly Review of Economics and Finance, 76, 379-385. https://doi.org/10.1016/j.qref.2019.09.005

Castaner, X., \& Kavadis, N. (2013). Does good governance prevent bad strategy? A study of corporate governance, financial diversification, and value creation by French corporations, 2000-2006. Strategic Management Journal, 34(7), 863-876. https://jstor.org/stable/23471071

Chen, S., \& Chen, I. (2012). Corporate governance and capital allocations of diversified firms. Journal of Banking and Finance, 36, 395-409. https:// doi.org/10.1016/j.jbankfin.2011.07.013

Chen, C. N., \& Chu, W. (2012). Diversification, resource concentration, and business group performance: Evidence from Taiwan. Asia Pacific Journal of Management, 29(4), 10451061. https:/ / doi.org/10.1007/s10490-010-9245-1

Claessens, S., \& Yurtoglu, B. B. (2013). Corporate governance in emerging markets: A survey. Emerging Market Review, 15(1), 1-33. https:// doi.org/10.1016.j.ememar.2012.03.002

Coleman, S., Cotei, C., \& Farhat, J. (2016). The debt-equity financing decisions of US startup firms. Journal of Economics and Finance, 40(1), 105-126. http:/ / dx.doi.org/10.1007/s12197-014-9293-3

Colli, A., \& Colpan, A. M. (2016). Business groups and corporate governance: Review, synthesis, and extension. Corporate Governance: An International Review, 24(3), 274-302. https:// doi.org/10.1111/corg.12144

Denis, D. J., Denis, D. K., \& Yost, K. (2002). Global diversification, industrial diversification, and firm value. Journal of Finance, 57(5), 1951-1979. https://doi.org/10.1111/00221082.00485

Delbufalo, E., Poggesi, S., \& Borra, S. (2016). Diversification, family involvement and firm performance: Empirical evidence from Italian manufacturing firms. Journal of Management Development, 35(5), 663-680. https:/ / doi.org/10.1108/JMD-09-2015-0129

Elsas, R., Hackethal, A., \& Holzhauser, M. (2010). The anatomy of bank diversification. Journal of Banking $\mathcal{E}$ Finance, 34, 1274-1287. https:// doi.org/10.1016/j.jbankfin.2009.11.024 
Elyasiani, E., \& Jia, J. (2010). Distribution of institutional ownership and corporate firm performance. Journal of Banking and Finance, 34(3), 606-620. https:// doi.org/10.1016.j.jbankfin.2009.08.018

Feng, Y., Yao, S., Wang, C., Liao, J., \& Cheng, F. (2021). Diversification and financialization of non-financial corporations: Evidence from China. Emerging Markets Review, https://doi.org/10.1016/j.ememar.2021.100834

Florackis, C., \& Ozkan, A. (2009). Managerial incentives and corporate leverage: Evidence from the United Kingdom. Accounting $\mathcal{E}$ Finance, 49(3), 531-553. https:// doi.org/10/1111/j.1467-629X.2009.00296.x

Franco, F., Urcan O., \& Vasvari, F. P. (2010). The value of corporate diversification: A debt market perspective. Working Paper.

Frank, M. Z., \& Goyal, V. K. (2003). Testing the pecking order theory of capital structure. Journal of Financial Economics, 67(2), 217-248. https://doi.org/10.1016/S0304405X(02)00252-0

Glaser, M., Lopez-De-Silanes, F., \& Sautner, Z. (2013). Opening the Black Box: Internal capital markets and managerial power. Journal of Finance, 68(4), 1577-1631. https:// doi.org/10.1111/jofi.12046

Guo, R. (2011). What drives firms to be more diversified? Journal of Finance and Accountancy, 6(1), 1-10.

Gyan, A. K., Brahmana, R., \& Bakri, A. K. (2017). Diversification strategy, efficiency, and firm performance: Insight from emerging market. Research in International Business and Finance, 42, 1103-1114. https:/ / doi.org/10.1016/j.ribaf.2017.07.045

Halabi, H., Alshehabi, A., Wood, G., Khan, Z., \& Afrifa, G. (2021). The impact of international diversification on credit scores: Evidence from the UK. International Business Review, https://doi.org/10.1016/j.ibusrev.2021.101856

Hann, R. N., Ogneva M., \& Ozbas, O. (2013). Corporate diversification and the cost of capital. Journal of Finance, 68(5), 1961-1999. https:// doi.org/10.1111/jofi.12067

Hoang, K., Nguyen, C., \& Zhang, H. (2021). How does economic policy uncertainty affect corporate diversification? International Review of Economics and Finance, 72, 254-269. https:// doi.org/10.1016/j.iref.2020.11.008.

Hund, J., Monk, D., \& Tice, S. (2010). Uncertainty about average profitability and the diversification discount. Journal of Financial Economics, 96(3), 463-484. https:/ / doi.org/10.1016/j.jfineco.2010.02.006

Jahera, J. S., \& Lloyd, W. P. (1996). An empirical assessment of factors affecting corporate debt levels. Managerial Finance, 22(2), 29-38. https:/ / doi.org/10.1108/eb018547

Jensen, M. C. (1986). Agency costs of free cash flow, corporate finance, and takeovers. American Economic Review, 76(2), 323-330. https:// doi.org/10.2139/ssm.99580

Jensen, M., \& Meckling, W. (1976). The theory of the firm: Managerial behavior, agency costs, and ownership structure. Journal of Financial Economics, 3(4), 305-360. https:/ / doi.org/10.1016/0304-405X(76)90026-X 
Ji, S., Mauer, D. C., \& Zhang, Y. (2019). Managerial entrenchment and capital structure: The effect of. Journal of Corporate Finance, https:// doi.org/10.1016/j.jcorpfin.2019.101505.

John, K., \& Litov, L. P. (2010). Managerial entrenchment and capital structure: New evidence. Journal of Empirical Legal Studies, 7(4), 693-742. https:/ / doi.org/10.1111/j.1740-1461.2010.01193.x

Jouida, S., \& Hellara, S. (2018). Diversification and target leverage of financial institutions. Journal of Multinational Financial Management, 46, 11-35. https:// doi.org/10.1016/j.mulfin.2018.06.001

Kuppuswamy, V., \& Villalonga, B. (2016). Does diversification create value in the presence of external financing constraints? Evidence from the 2007-2009 financial crisis. Management Science, 62(4), 905-923. https:/ / doi.org/10.2139/ssrn.1569546

La Rocca, M., La Rocca T., Gerace D., \& Smark, C. (2009). Effect of diversification on capital structure. Accounting \& Finance, 49(4), 799-826. https://dx.doi.org/10.1111/j.1467629X.2009.00304.x

La Rocca, M., La Rocca T., \& Vidal, F. J. S. (2018). Multibusiness firms and performance in Italy. What role does relatedness play? European Research on Management and Business Economics, 24(2), 63-70. https:/ / doi.org/10.1016/j.iedeen.2018.01.001

Lee, K. T., Hooy, C. W., Hooy, \& G. K. (2012). The value impact of international and industrial diversifications on public-listed firms in Malaysia. Emerging Markets Review, 13(3), 366-380. https:/ / doi.org/10.1016/j.ememar.2012.06.001

Levinthal, D. A., \& Wu, B. (2010). Opportunity costs and non-scale free capabilities: Profit maximization, corporate scope, and profit margins. Strategic Management Journal, 31(7), 780-801. https:// doi.org/10.1002/smj-845

Lewellen, W. G. (1971). A pure financial rationale for the conglomerate merger. Journal of Finance, 26(2), 527-537. https:/ / doi.org/10.1111/j.1540-6261.1971.tb00912.x

Ljubownikow, G., \& Ang, S. H. (2020). Competition, diversification and performance. Journal of Business Research, 112, 81-94, https:// doi.org/10.1016/j.jbusres.2020.03.002

Mackey, T. B., Barney, J. B., \& Dotson, J. P. (2017). Corporate diversification and the value of individual firms: A Bayesian approach. Strategic Management Journal, 38(2), 322341. https://doi.org/10.1002/smj.2480

Mansi, S., \& Reeb, D. (2002). Corporate diversification: What gets discounted?. Journal of Finance, 57(5), 2167-2183. https:/ / doi.org/10.1111/0022-1082.00492

Modigliani, F., \& Miller, M. H. (1958). The cost of capital, corporation finance and the theory of investment. American Economic Review, 48(3), pp. 261-297. https://www.jstor.org/stable/1809766

Monteforte, D., \& Stagliano, R. (2015). Firm complexity and capital structure: Evidence from Italian diversified firms. Managerial and Decision Economics, 36(4), 205-220. https:// doi.org/10.1002/mde.2660 
Montgomery, C. A. (1982). The measurement of firm diversification: Some new empirical evidence. Academy of Management Journal, 25(2), 299-307. https:// doi.org/10.2307/255992

Myers, S. C., \& Majluf, N. S. (1984). Corporate financing and investment decisions when firms have information that investors do not have. Journal of Financial Economics, 13(2), 187-221. http:/ / dx.doi.org/10.1016/0304-405X(84)90023-0

OECD. (2015). G20/OECD Principles of Corporate Governance. OECD Publishing, Paris. http://dx.doi.org/10.1787/9789264236882-en

Purkayastha, A., Pattnaik, C., \& Pathak, A. A. (2021). Agency conflict in diversified business groups and performance of affiliated firms in India: Contingent effect of external constraint and internal governance. European Management Journal, https:// doi.org/10.1016/j.emj.2021.05.004

Qureshi, M. A., Akhtar, W., \& Imdadullah. M. (2012). Does diversification affect capital structure and profitability in Pakistan?. Asian Social Science, 8(4), 30-42. https:// doi.org/10.5539/ass.v8n4p30

Rajan, R., Servaes, H., \& Zingales, L. (2007). The cost of diversity: The diversification discount and inefficient investment. Journal of Finance, 55(1), 35-80. https:// doi.org/10.1111/0022-1082.00200

Ramaswamy, K., Purkayastha, S., \& Petitt, B. S. (2017). How do institutional transitions impact the efficacy of related and unrelated diversification strategies used by business groups? Journal of Business Research, 72, 1-13. https://10.1016/j.jbusres.2016.11.005

Sakhartov, A. V., \& Folta, T. B. (2015). Getting beyond relatedness as a driver of corporate value. Strategic Management Journal, 36(13), 1939-1959. https:// doi.org/10.1002/smj.2327

Scharfstein, D. S., \& Jeremy, C. S. (2000). The dark side of internal capital markets: Divisional rent-seeking and inefficient investment. Journal of Finance, 55(6), 2537-2564. https:// doi.org/10.1111/0022-1082.00299

Schommer, M., Richter, A., \& Karna, A. (2019). Does the diversification-firm performance relationship change over time? A meta-analytical review. Journal of Management Studies, 56(1), 270-298. https:/ / doi.org/10.1111/joms.12393

Shanker, D. (2012). Crimes of the Century: Enron. Hyperink, San Francisco.

Shleifer, A., \& Vishny, R. W. (1992). Liquidation values and debt capacity: A market equilibrium approach. Journal of Finance, 47(4), 1343-1366. https:// doi.org/10.1111/j.1540-6261.1992.tb04661.x

Singh, M., Davidson, W., \& Suchard, J. (2003). Corporate diversification strategies and capital structure. The Quarterly Review of Economics and Finance, 43, 147-167. https:// doi.org/10.1016/S1062-9769(02)00124-2

Stulz, R. (1990). Managerial discretion and optimal financing policies. Journal of Financial Economics, 26(1), 3-27. https://doi.org/10.1016/0304-405X(90)90011-N 
Tate, G. A., \& Yang, L. (2015). The bright side of corporate diversification: Evidence from internal labor markets. Review of Financial Studies, 28(8), 2203-2249. https://doi.org/10.1093/rfs/hhv012

Teruel, P. J. G., Solano, P. M., \& Ballesta, J. P. S. (2014). Supplier financing and earnings quality. Journal of Business Finance $\mathcal{E}$ Accounting, 41(9-10), 1193-1211. https:// doi.org/10.1111/jbfa.12090

Teruel, P. J. G., \& Solano, P. M. (2005). Effects of working capital management on SME profitability. International Journal of Managerial Finance, 3(2), 164-177. http:/ / dx.doi.org/10.1108/17439130710738718

Vijayakumaran, R. (2019). Agency costs, ownership, and internal governance mechanisms: Evidence from Chinese Listed Companies. Asian Economic and Financial Review, 9(1), 133-154. https://doi.org/10.18488/journal.aefr.2019.91.133.154

Villalonga, B. (2004). Diversification discount or premium? New evidence from the business information tracking series. Journal of Finance, 59(2), 479-506. https:// doi.org/10.1111/j.1540-6261.2004.00640.x

Wang, Y., Ning, L., \& Chen, J. (2014). Product diversification through licensing: Empirical evidence from Chinese firms. European Management Journal, 32(4), 577-586. https:// doi.org/10.1016/j.emj.2013.09.001

Weston, J. F. (1970). The nature and significance of conglomerate firms. St. John's Law Review, $44(5), 66-80$.

Xuan, T., \& Nguyen, T. (2018). Corporate governance and conglomerate diversification strategy-evidence from Vietnam. International Journal of Emerging Markets, 13(6), 15781596. https:// pea.lib.pte.hu/handle/pea/23361 